\title{
The Use of Blended Learning Models in the Process of Business English Language Studying
}

\author{
Khmyzova 0.* \\ Petro Mohyla Black Sea National University, Mykolayiv, Ukraine
}

Received: $14.06 .2019 \quad$ Accepted: 18.09 .2019

\begin{abstract}
Intercultural integration and changing settings in the modern world require implementing the new models of foreign languages studying. The use of blended learning models contributes to the individualization, intensification, and optimization of the educational process in higher education. The multidimensional issue of Business English Language blended learning in a higher education institution requires the solution of a complex of organizational, educational, methodical, material, technical, and other tasks. The aim of the paper is to analyze the blended learning concept and to specify the main components of designing and implementing blended Business English language course in a higher education training program. The modern interpretations of blended learning concept in the context of the research are analyzed; different blended learning models are looked at; the implications of the blended learning model in the Business English language course are presented; the specifics of blended learning using in the activities of a teacher and students are revealed. In particular, it is shown that blended learning does not follow a universal formula, researchers tend to use this term contextually nowadays; the number of different ways to blend learning opportunities and environments is potentially limitless, and certain factors need to be considered in order to achieve a blend that is appropriate to the needs of teachers and students. It is highlighted that the current blended learning methodology suggests five phases, namely: needs assessment, instructional design, content creation, delivery methods, and evaluation strategies. The original blended Business English language course is presented. It has the following components: target audience; desired learning outcomes (professional competences); time available for learning; content of training (tasks, interaction, instructional modalities, and methods); evaluation; context of training (the accessibility of technology, location, and availability of training resources). The implemented Business English language blended course combines two formats: face-to-face learning and Moodle-based distance learning. In addition, the methods, forms, and means of blended learning are described, and the advantages of the blended learning model and some problems of its implementation are highlighted.
\end{abstract}

Key words: blended learning; scientific approaches; blended learning strategy; blended learning model; methods, forms and ways of blended learning.

\section{Використання моделей змішаного навчання у процесі вивчення ділової англійської мови}

\author{
Хмизова О. В. \\ Чорноморський національний університет імені Петра Могили, м. Миколаїв, Україна
}

\begin{abstract}
Анотація. Міжкультурна інтеграція та швидкі зміни у сучасному світі потребують впровадження нових моделей навчання іноземних мов. Використання змішаного навчання сприяє індивідуалізації, інтенсифікації та оптимізації навчального процесу у вищій освіті. Багатоаспектне питання змішаного навчання ділової англійської мови у закладах вищої освіти України потребує вирішення комплексу організаційних, навчальнометодичних, матеріально-технічних та інших завдань. Метою публікації $€$ аналіз концепції змішаного навчання, визначення основних компонентів розробки і впровадження змішаного курсу ділової англійської мови у програму закладу вищої освіти. Проаналізовано сучасні трактування поняття «змішане навчання»; розглянуто моделі змішаного навчання; визначено особливості використання змішаного навчання у діяльності суб'єктів освітнього процесу - викладача і студентів. Зокрема, показано, що змішане навчання не має універсальної формули, дослідники, як правило, використовують цей термін контекстуально; кількість різних способів поєднання навчальних можливостей та середовища $€$ потенційно безмежною, і необхідно враховувати певні фактори, щоб досягти поєднання, яке відповідає потребам і цілям викладачів і студентів.
\end{abstract}

Corresponding Author: Khmyzova Olga Vasylivna. Tel. +38(095) 4116745. E-mail: sunnyflowers22@gmail.com Petro Mohyla Black Sea National University, 68 Desantnykiv street, 10, Mykolaiv, Ukraine, 54003.

Відповідальний автор: Хмизова Ольга Василівна. Тел. +38(095) 4116745. E-mail: sunnyflowers22@gmail.com чНУ ім. Петра Могили, вулиця 68 Десантників, 10, Миколаїв, Україна, 54003. 
Підкреслено, що сучасна методологія змішаного навчання передбачає п'ять етапів: аналіз потреб, розробку навчальних програм, створення контенту, вибір методів доставки та стратегій оцінювання. Представлено авторський курс змішаного навчання ділової англійської мови, який містить наступні компоненти: цільова аудиторія; результати навчання (професійні компетенції); час навчання; зміст навчання (завдання, взаємодія, умови та методи навчання); оцінювання; контекст навчання (доступність технології, місце розташування, наявність навчальних ресурсів). Впроваджений змішаний курс ділової англійської мови поєднує два фрормати: очне навчання та дистанційне навчання з використанням платформи Moodle. Також описано методи, форми організації та засоби, які використовуються в змішаному навчанні, висвітлено переваги такої моделі навчання і проблеми їі впровадження.

Ключові слова: змішане навчання; наукові підходи; стратегія змішаного навчання; модель змішаного навчання; методи, форми організації та засоби навчання.

\title{
Использование моделей смешанного обучения в процессе изучения делового английского языка
}

\author{
Хмызова О. В. \\ Черноморский национальный университет имени Петра Могилы, г. Николаев, Украина
}

\begin{abstract}
Аннотация. Межкультурная интеграция и быстрые изменения в современном мире требуют внедрения новых моделей обучения иностранным языкам. Использование смешанного обучения способствует индивидуализации, интенсификации и оптимизации учебного процесса в высшем образовании. Многоаспектный вопрос смешанного обучения деловому английскому языку в учреждениях высшего образования Украины требует решения комплекса организационных, учебно-методических, материальнотехнических и иных задач. Целью публикации является анализ концепции смешанного обучения; основных компонентов смешанного курса делового английского языка и его внедрения в программу высшего учебного заведения. Проанализированы современные трактовки понятия «смешанное обучение»; рассмотрены различные модели смешанного обучения; определены особенности использования смешанного обучения в деятельности субъектов образовательного процесса - преподавателя и студентов. Так, показано, что смешанное обучение не имеет универсальной формулы, данное понятие рассматривается исследователями контекстуально; количество различных сочетаний образовательных возможностей и среды потенциально неограниченно; необходимо учитывать определенные фракторы, чтобы достичь сочетания, соответствующего потребностям и целям преподавателей и студентов. Подчеркнуто, что современная методология смешанного обучения предполагает наличие пяти этапов: анализ потребностей, разработку учебных програм, создание контента, выбор методов доставки и стратегий оценивания. Представлено авторский курс смешанного обучения деловому английскому языку, содержащий следующие компоненты: целевая аудитория; результаты обучения (профессиональные компетенции); время обучения; содержание обучения (задания, взаимодействие, условия и методы обучения); оценивание; контекст обучения (доступность технологии, расположение и наличие учебных ресурсов). Внедрённый курс смешанного обучения деловому английскому языку объединяет два формата: очное обучение и дистанционное обучение с использованием платформы Moodle. Также описаны методы, формы организации и средства, которые используются в смешанном обучении, освещены преимущества такой модели обучения и проблемы ее внедрения.

Ключевые слова: смешанное обучение; научные подходы; стратегия смешанного обучения; модель смешанного обучения; методы, формы организации и способы обучения.
\end{abstract}

\section{Introduction}

The rapid change of technological innovations has had a great impact on the possibilities for language courses in higher business education establishments and facilitated a convergence between traditional faceto-face and distributed (or technology-mediated) learning environments. The blended learning methodology tries to take advantage of the strengths of both archetypal learning environments [3] by using new channels and technologies for obtaining knowledge, conducting tailor-made strategy and objective assessment and taking into consideration people, interaction, time, location, and the tasks specific to professional business activities. In the world, in educational programs of companies, schools, and universities, the blended learning model is accepted in line with increased digitization. Blended learning is one of the main trends in higher education in the past five editions of the NMC Horizon Report [1].

The higher education system in Ukraine is undergoing significant reforms. The purpose of the research is to create a technology within which students would develop their leadership skills/competences and their 
English language learning would be rewarded and contextualized. Whilst improving a better understanding of the role of the business leader/businessperson, they would gain a better understanding of themselves as learners. This, in turn, would enhance their self-esteem and confidence, improve their communicative, analytical and evaluative skills and increase their personal attainment in a foreign language. Blended learning may be one of the components/tools/means of experimental technology.

The concept of blended learning has a broad range of interpretations in the current educational literature. More specifically, blended learning is:

- any combination of different methods of learning, different learning environments, different learning styles [16];

- formal education programs that mix online learning and brick-and-mortar schools [6];

- the combination of two fields of concern: education and educational technology [5];

- a purposeful process of obtaining knowledge, skills and capabilities, mastering the ways of cognitive activity by the subject of learning and developing his/her creative abilities on the basis of the integrated and systematic use of traditional and innovative pedagogical technologies, information and communication technologies of learning by the principle of mutual complementarity in order to improve the quality of education [24];

- a formal education program in which a student learns in part through online delivery of content and instruction with some element of student control over time, place, path, and/or pace and in part at a supervised location away from home [23];

- using the best delivery methodology(ies) available for a specific objective, including online, classroombased instruction, electronic performance support, paper-based, and formalized or informal on-the-job solutions [12].

It can be concluded that researchers tend to use this term contextually nowadays. Friesen, who conducted a historical and etymological study of this concept, argued that in the early days of blended learning, there were four commonly used interpretations [9]:

1) the combination of the modes of web-based technology in order to accomplish educational goals,

2) the mix of pedagogical approaches in order to produce an optimal learning outcome with or without instructional technology,

3) the usage of any instructional technology with face-to-face training, working.

4) the instructional technology plus actual job tasks in order to create a high effect of learning and

Oliver and Trigwell argued that by focusing on the modes of delivery, theorists were actually focusing more on teaching than on learning. This critique might be disputed, but it highlighted the danger of using technology without adequately considering how it contributes to the learning process $[4 ; 19]$.

The terms "blended", "hybrid", "web-enhanced instruction", "technology-mediated instruction", and "mixed-mode instruction" are often used interchangeably in research literature [18]. Friesen emphasized that blended learning is any combination of technologies, pedagogies, and even job tasks [9]. Masie gave another broad definition that is often cited. It includes "combinations such as blending classroom instruction with online instruction, blending online instruction with access to a coach or faculty member, blending simulations with structured courses, blending on-the-job training with informal sessions, blending managerial coaching with informal educational programs that combine online digital resources and media with traditional e-learning activities" [7, p. 4]. In this eclectic view, the concept may provide a wide potential for educational purposes.

The aim of this paper is to analyze the blended learning concept and to specify the main components of designing and implementing blended Business English language course in a higher education training program. To achieve this the following tasks are to be solved: 1) investigating the meaning of the term, 2) looking at different blended learning models; 3) presenting the implications of the blended learning model in the Business English language course, considering the rationales for adopting them and the challenges involved in their usage. 


\section{Materials and Methods}

This study is based on a review of the literature available on the Internet, which consist of mainly opensource articles found on Google Scholar by using the Boolean search method. Most of the literature is in one or more of the following categories: white papers; unpublished papers, such as blog posts by researchers with an international reputation; reports by governmental or nonprofit organizations; scientific journals and books. The paper focuses on past studies and on the results of blended learning model implementation in Business English language course using Moodle platform. Based on these ones, it tries to fulfill the aim.

Nowadays, most teachers and students use blended learning methodologies, but many are unaware that they are using them [11]. An example of blended learning would be "an integrated combination of technology-based materials and face-to-face sessions to present content to students" [11, p.5].

The Christiansen Institute offered the most-often cited definition of this term: "Blended learning is a formal education program in which a student learns: at least in part through online learning, with some element of student control over time, place, path, and/or pace; at least in part in a supervised brick-and-mortar location away from home; and the modalities along each student's learning path within a course or subject are connected to provide an integrated learning experience" [6, p. 8].

Oliver and Trigwell proposed that blended learning is based on a mixture of two or more components, such as various means of information delivery, different pedagogical approaches, combining theoretical and practical work within one course [19]. Graham et al. analyzed definitions of blended learning at the course level and synthesized them into three categories:

1) instructional modalities,

2) instructional methods,

3) face-to-face instruction and computer-mediated instruction [3; 10].

The term blended learning is commonly understood as referring to the mix of online and classroom learning. Blended learning environments include not only the physical presence of teachers and students but also the students' control of the time, place, setting, path, and pace of learning. Blended learning is considering as learner-centered, that offers flexibility throughout the educational process. Interpretations of the concept of blended learning have varied over time. The term has been used since the advent of the Internet and the World Wide Web in the late 1990s. Although the concept was first developed in the 1960s, the formal terminology used to describe it did not take its current form until the late 1990s [9].

This paper is an educational survey aimed to revisit current blended learning models from educationists' point of view. Although blended learning does not follow a universal formula, the number of different ways to blend learning opportunities and environments is potentially limitless, and many factors need to be considered in order to achieve a blend that is appropriate to the needs of students [16]. Nevertheless, there are four wellknown models of this process, namely [6;23]:

1) Rotation model - students succeed on a fixed schedule or at the teacher's discretion among learning modalities, for example, small-group or full-class instruction, group projects, individual tutoring, and pencil-andpaper assignments at least one of which is online.

There are four sub-models: a) the Station Rotation model (Classroom Rotation / In-Class Rotation) students rotate within a contained classroom;

b) Lab Rotation model - the blend occurs between a classroom and a learning lab for online learning;

c) Flipped Classroom model - the mix occurs between the school for face-to-face teacher-guided practice and the home or other off-site location for online content and instruction;

d) Individual Rotation model - students have individualized playlists and do not necessarily alternate doing something on each available station or with modality.

2) Flex model - online learning is the main part of students' learning, even if it directs them to offline activities at times. Students move on an individually customized, fluid schedule among learning modalities, and the tutor of record is on-site.

3) A La Carte model - students take one or more courses entirely online with an online tutor of record and at the same time continue to have classroom education;

4) Enriched Virtual model - students study each course dividing their time between attending the university and online learning. 
The intent of Figure 1 is to situate these blended learning models among other education practices (such as traditional instruction, technology-rich instruction, informal online learning, and full-time virtual learning) for the purpose of differentiation [23].

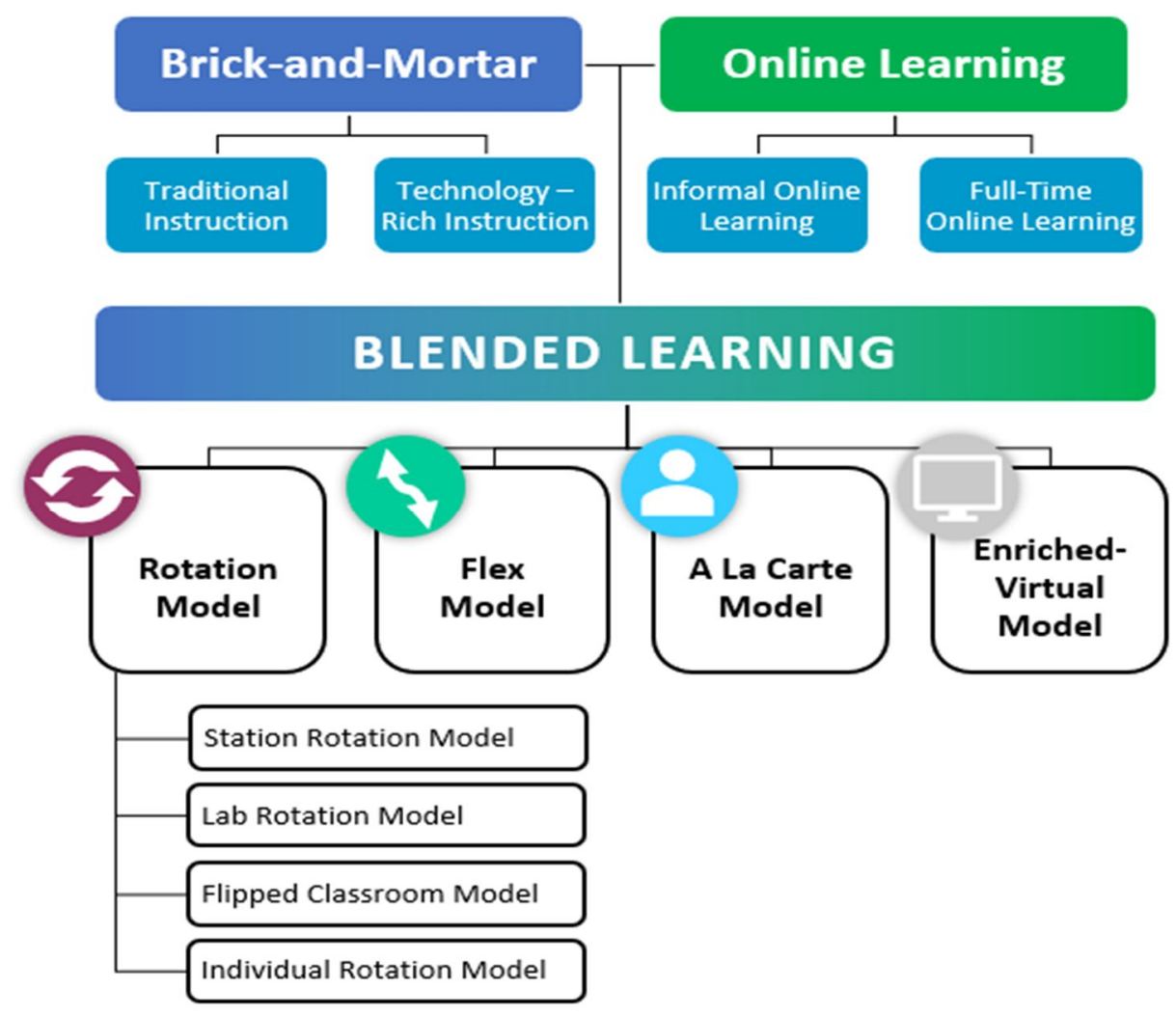

Fig. 1. Blended learning in relation to other education practices [23, p. 5]

Thus, Staker and Horn argued that traditional instruction and technology-rich instruction "are not in and of themselves forms of blended learning, but they can combine with online learning to create a blendedlearning experience for students" [23, pp. 5-6].

Chew et al. examined four other models of blended learning (Gill Salmon's structured E-moderation Model, Sun Microsoft Systems' "Learning Ecology" Model, documented by Wenger and Ferguson, Blended Learning Continuum, Inquiry-based Framework by Garrison and Vaughan) and introduced a theoretical basis for critiquing them, by using Vygotsky's and Maslow's insights into learning [5;4].

Graham suggested classifying blended learning models according to four dimensions, four levels, and three types. The four dimensions are space (face-to-face/virtual), time (synchronous/asynchronous), sensual richness (high, all senses/low, text only) and humanness (high human, no machine/low human, high machine). These are related to the idea of blended learning as defined by bimodal delivery. The second element of his classification is introduced by organization level: activity, course, program and institution. Across all four levels, the nature of the blends is determined either by the student or by the educator and using blended methods for individual learning activities is quite different from blended learning as an institution wide approach. Finally, Graham introduced three different categories of blend, related to purpose: enabling blends (they focus on access and flexibility); enhancing blends (they seek to supplement traditional pedagogy); and transformative blends (they are aimed at changing pedagogy) [10; 4]

To construct blended learning environment educationists may combine such components as face-toface education, synchronous conversations, and asynchronous interactions [25]. Teachers have a variety of choices, which includes delivery platforms and software for online learning; classroom (live or virtual), workshops (live or virtual); books (hard copy or virtual), websites, online advertisements, simulations, and other ones. More specifically, Marsh [16] proposes a blended solution for language learning, emphasizing 
such teachers' roles in the blend as promoting student-centered learning in the classroom, facilitating the blend, creating a supportive online community, managing and facilitating online interaction.

There are many reasons why a teacher, tutor, or student can choose blended strategy among other learning options. For example, pedagogical richness, social interaction, personal agency, access to knowledge, cost-effectiveness, and ease of revision [20]. In addition, the choice of delivery platform and software influences on what instructional methods and media elements can be included in the course [7].

Majumdar proposed four forms of blended learning, namely [15]:

1) Blending Offline and Online Learning: classes are supported by online learning opportunities to create a "flipped" model, where all material (documents, notes, question sheets, audio recordings, videos, animations and infographics) is shared online - post or prior to the classroom session.

2) Blending Structured and Unstructured Learning: for example, training where the learner receives a set of pre-designed content and methods is blended with conversations, meeting, e-mails, and online social platforms with problem-solving forums. Instructors are moderators providing the necessary direction for fruitful interactions.

3) Blending Custom Content with Off-the-Shelf Content: this blend provides a well-rounded learning experience for the student's combining the technical "know-how" in particular industry, product or process, and individual skills in his/her professional area.

4) Blending Self-paced and Live/Collaborative learning: technology has created means for self-paced or asynchronous learning and for delivering live trainings to multiple locations and groups. This blend is a recipe for training success in interactions with instructors and peers. It can be one-way (an instructor delivers a session on a virtual platform - a presentation, podcast or live video) or two-way interaction (virtual classroom with voice messages).

Thus, there are three main aspects of the definition: levels of implementation (institutional, program and course ones), learning environments and the amount of time spent in the classroom. Researchers [5; 11] argued that some models are better than others and it is impossible to design a perfect model as blended learning resides in the field of education rather than in computer science.

\section{Results}

The Moodle-based blended learning study was conducted in Petro Mohyla Black Sea National University (Mykolayiv, Ukraine) in 2017 - 2018, 2018 - 2019 studying years. It was a purposeful process of blended learning models implementation in solving Business English language tasks from the scope of future professional activities of economists using Moodle platform.

Moodle has been chosen because it is one of the most effective systems designed to help teachers to build online courses with a number of different modules. Incorporation of new modules guarantees the functionality of its use and provides the possibility of adding or suppressing material (lessons, tests, and resources) by using online tools. The platform focuses on giving teachers the best means to manage learning and allows useful organizing and delivering course materials. Moodle provides the integration of a wide range of resources, a variety of questions, glossaries, tests, cases, exercises, lectures (including text-based or Htmlformatted documents), multimedia resources (audio, video, graphics, PowerPoint presentation, Flash-based applications), forums and chats.

Modern blended learning methodology suggests five phases: needs assessment, instructional design, content creation, delivery methods, and evaluation strategies.

To design a blended Business English language course the following components were taken into consideration:

- target audience;

- desired learning outcomes (professional competences);

- time available for learning;

- content of training (tasks, interaction, instructional modalities, and methods);

- evaluation (timely, clear, and concise feedback);

- context of training (the accessibility of technology, location, availability of training resources).

The process of Business English language blended learning had two formats: face-to-face learning and Moodle-based distance learning. 
Firstly, it was necessary to decide what kinds of activities should be used in distance learning based on Moodle platform. There were texts, grammar exercises, short video and audio lessons conducted by native speakers, project activities, individual tasks, tests, online forums and chats, supplementary reading of business articles/posts in magazines, journals, and newspapers. Then it was necessary to decide what kinds of activities should be used in the face-to-face learning.

Before the study started, the diagnostic test was applied to the students to identify their language levels. Overview classes were used to identify students' speaking skills, interests and needs. Based on this information, the syllabus was adapted to new requirements. Then, the students were informed about the blended learning model and about what they were expected to do. Moodle platform was introduced to the students via the Internet with the help of a computer connected to a projector in the classroom. They were demonstrated how to sign up Moodle and what to pay attention to while following up the activities. While teaching the classes, a balance between the face-to-face and online environments was established as appropriate to the identified goals. Before coming to the classroom, the students could prepare themselves by examining the summary of the unit, the presentations, the videos and audios related to the topic, using the dictionaries and the other related links via the Internet.

In addition, the students were given the homework (vocabulary and grammar exercises, online quizzes, listening, writing and watching tasks) that they were supposed to do before coming to the classroom. The students were asked either to present the assignments to the classroom or to send their homework online. The students were announced to be expected to work at least 1 hour a week to carry out the activities in Moodle.

The assignments were presented and the topics were also taught in face-to-face learning via different methods. The teacher evaluated the activities carried out via Moodle and clarified the details that were not understood by the students. At the end of each module, a test/quiz was included. Face-to-face instruction was used for intermediate and final control (examinations), assignments/projects results presentation and individual consultations to help students to cope with difficulties.

The students were able to see the announcements on screen under the heading of the latest news. To create more effective environment different learning and teaching techniques were used. The students were able to follow up the unit via the Unit page, presentations, animations, and related websites. In addition, there were image galleries, dictionaries, and a forum. The systems allowed determining the students' sign in and sign out time, and the duration of the time, they spent on the activities. Such information provided the teacher with the opportunity to guide the students.

Business English language blended learning combined practical and theoretical materials. Each module had Listening, Reading, Writing, Speaking, Grammar, Vocabulary and Test Units. For example, Reading and Writing Units (Business letters, Business premises, Business reports, Business negotiations, etc.), Grammar and Vocabulary Units (Business vocabulary, Finance vocabulary, Money vocabulary, Work vocabulary, etc.) presented numerous activities to develop professional competences of learners. Working with terms, different business phenomena and processes enabled students to generalize diverse facts and systematize them. Most students demonstrated independent and responsible attitude toward establishment of personal training goals; designed the education trajectories and integrated them into everyday life; picked up appropriate methods and learning tools; regular tracked their own learning progress with the formation of specific professional competencies and development of their leadership skills/competences.

Students solved cases (business problems), read articles, wrote research/business papers, made diagrams or tables summarizing the theoretical material, projects, etc. The results (knowledge, experience, a method of application, etc.) were presented and discussed in the group and with the teacher. The defenses of the created products were also compulsory. Thus, professional competencies were improved, modified and completed.

Analysis of scientific sources and the process of Moodle-based blended Business English language learning survey resulted in singling out of the main advantages of using this model. Thus, for teachers this model provided:

- implementing an individual approach;

- coverage many participants in training;

- interactivity (combining face-to-face and online learning environments);

- increasing computer literacy and 
- the effectiveness of teaching activities in order to achieve new educational outcomes.

For students, this model was useful for

- improving motivation and interest in learning;

- getting simultaneous and independent learning experience;

- self-assessing of material understanding with help of computer-based test units;

- developing of ability to organize and plan work independently, receive and analyze knowledge, search and select information, make decisions and be responsible for them;

- presenting the results of activities using various information technologies;

- formation of self-development and self-education.

Among the main drawbacks of this form of education in Ukraine, a great deal of dependence on the technical means of training and equipping of the audience (the Internet, stability of online mode and tariffs) were mentioned. In addition, inefficient students' time management and lack of self-discipline, uneven computer literacy were presented. Blended training required constant technical support and certain costs for the creation of materials, training programs and testing modules. However, material costs could be significantly reduced, using free content competently.

\section{Discussion}

The implications of the different models for practitioners of blended learning depend on the intended goals of its adopting, and on how successfully the challenges of its implementing are met [4]. There is no singular best-blended learning model, and most institutions can achieve success with any of them [8]; the mode of delivery has a very weak statistical correlation with student success or persistence. For an institution to succeed in blended learning it must have institutional goals, faculty goals, and student goals. An initial blended learning strategy may consist of:

1) the institution's goals, outcomes (in initial and longer terms);

2) students' benefits;

3) courses or programs offered in a blended format;

4) engagement and support of the faculty;

5) spread of blended learning throughout the institution;

6) prepared levels of investments and expected returns [17].

The main task of teachers is to compose a course and distribute the educational material. It is necessary for them to decide what must be done in class, what can be mastered and studied at home, what tasks are good for individual classes and for group work [3, p. 585].

Marsh has proposed four steps to start designing blended learning:

1) Identification of the learning outcomes for classroom lessons;

2) description of the activities for students to do in class;

3) proposition of the activities for students to do online before class;

4) indication of the activities for students to do after class [16].

The lecturer may teach an introductory class and then proceed with follow-up materials online, making use of blogs, virtual learning environments, or social networks [13]. The starting point for devising any efficient teaching technique must be by considering students' perspectives [11].

The biggest debate revolves around pedagogical effectiveness. One advantage of blended learning is that it has the potential to accommodate different learning styles [4]. Researchers provide a useful framework for the design of courses in which leadership and foreign languages are combined [22]:

1a. Generic (approaches or strategies for leadership that may occur in any discipline (i.e., team/group work, presentational assignments);

1b. Discipline-Specific (approaches or strategies for leadership that are particular to the fields due to foreign languages' unique access to insider cultural perspectives (i.e., learning about cultural differences of doing business through scenarios);

2a. Explicit (approaches or strategies for leadership that are directly stated to students (i.e., an explanation of managers' responsibilities);

2b. Implicit: (approaches or strategies for leadership are indirect (i.e., mentoring, role modeling) and the link between the activity and leadership is not explicitly acknowledged or discussed. 
It is highly important for teachers to be considerate to the main challenges facing designing and implementing the blended methodology. As identified by Hofmann, they can be grouped into three categories: technical, organizational, and instructional ones [12]. Higgins and Gomez pointed out some key issues connected with English language blended learning, namely [11]: the limitations of VLEs, viability and sustainability of resources, assessing online activities, opportunities of technology, peer review and assessment, podcasts and lectures, learning from failure, group sizes, motivation and gamification, skills.

Bonk et al. [3, pp. 560-564] pointed out ten trends of blended learning expansion, namely:

1) mobile blended learning;

2) visualization, individualization, and hands-on learning;

3) self-determined blended learning;

4) increased community, connectedness, and collaboration;

5) increased authenticity and on-demand learning;

6) linking work and learning;

7) changed calendaring;

8) blended course designations;

9) changed instructor roles;

10) the emergence of blended learning specialists.

Thus, there is a range of tools and technologies used for constructing effective blended learning environments, namely [11]:

a) face-to-face learning technologies (interactive whiteboards, PowerPoint presentation, audience response systems, etc.);

b) virtual communication tools (chat or conferencing, audio files, discussion boards, e-lists, email, newsgroups, polling, questionnaires, etc.);

c) social-networking software (messaging or phone calls, podcasts, social-network sites, video clips, blogs, etc.);

d) e-learning systems (online environments: conferencing systems, group collaboration software and group sites);

e) mobile learning using cell phones / laptops.

It is often difficult for teachers and institutions to keep pace with new landscapes of an education process. They should have the freedom to find their own ways of blending, so that it enhances learning and teaching, and potentially saves resources. Universities often support teaching innovations, but they should emerge organically as a response to pedagogical problems and not occlude traditional forms of good educational practice [11].

\section{Conclusion}

Professional development is a lifelong process. Analyzing the experience of studying Business English, we have considered it necessary to draw attention to some peculiarities of teachers and students using blended learning model in an educational process. Thus, blended Business English language course offers the advantages of classroom-based training integrated with the effectiveness and flexibility of e-learning, combining individual tutoring, interactive learning, group discussion, and self-study. Blended learning model requires constant technical support and certain costs for the creation of materials, training programmes and testing modules.

Blended learning has been defined in different ways by the authors, and still new interpretations are evolving. It is beneficial to the institutions, teachers and students.

Thus, students have found the opportunity:

- to be involved in the learning process, to be more motivated;

- to learn on individual pace, building their own education trajectory, not to depend on their teachers' instructions all the time;

- to cooperate and to communicate with other students in pairs and small groups;

- to evaluate peers' contributions respectivly;

- to use the opportunity to make revision/tests at a suitable time and

- to understand the subject better via such activities as videos, animations, quizzes in the Moodle. 
In this process, the language teacher guides students, manages their activities, directs their learning and helps them to develop professional competences and skills. Moodle platform provides teachers with many advantages, namely:

- availability of numerous online resources;

- a clear view of all learning activities and resources for every module;

- an easy uploading of new articles, exercises and activities during the course;

- flexibility in task assessment and grading students' activity.

The nature of learning in higher business education is changing - presenting both challenges and opportunities in the shape of colossal online resources and new methods of teaching. The concept of blended learning model is facilitating the educational process using new channels and technologies for development of leadership and communication competences.

\section{References}

1. Adams Becker, S., Cummins, M., Davis, A., Freeman, A., Hall Giesinger, C., Ananthanarayanan, V. (2017). NMC horizon report: 2017 higher education edition. Austin, Texas: The New Media Consortium.

2. Blended Learning Methodology. URL: http://web.archive.org/web/ 20040607002543/ http://www.sselearn.com:80/ blendedLearning.aspx (accessed 27.05.2019).

3. Bonk, C. J., Graham, C. R. (2006). The Handbook of Blended Learning: Global Perspectives, Local Designs. San Francisco, CA: Pfeiffer.

4. Bryan, A., Volchenkova, K. (2016). Blended learning: definition, models, implications for higher education. Bulletin of the South Ural State University. Education. Educational Sciences, 8 (2), 24-30. doi: https://doi.org/10.14529/ped160204

5. Chew E., Jones N., Turner, D. (2008). Critical Review of the Blended Learning Models Based on Maslow's and Vygotsky's Educational Theory' in Hybrid Learning and Education. ICHL 2008: Hybrid Learning and Education. Berlin, Springer Verlag Publ., 40-53. doi: https://doi.org/10.1007/978-3-540-85170-7_4

6. Christensen, C., Horn, M., Staker, H. (2013). Is K-12 Blended Learning Disruptive? An introduction to the theory of hybrids. Clayton Christensen Institute. URL: https://www.christenseninstitute.org/wp-content/uploads/2014/06/ls-K-12-blendedlearning-disruptive.pdf (accessed 17.05.2019).

7. Clark, R. T., Meyer, R. E. (2007). E-Learning and the Science of Instruction: Proven Guidelines for Consumers and Designers of Multimedia Learning [2nd Edition]- San Francisco: Pfeiffer, 2007.

8. Dziuban, C., Hartman, J., Cavanagh, T., Moskal, P. (2011). Blended courses as drivers of institutional transformation. In A. Kitchenham (Ed.)(2011). Blended learning across disciplines: Models for implementation. Hershey, PA: IGI Global.

9. Friesen, N. (2012). Report: Defining Blended Learning. URL: http://learningspaces.org/ papers/ Defining_ Blended_ Learning_NF.pdf (accessed 23.04.2019).

10. Graham, C.R. (2006). Blended Learning Systems: Definition, Current Trends, and Future Directions. In C. J. Bonk \& d C. R. Graham (2006). The Handbook of Blended Learning: Global Perspectives, Local Designs. San Francisco, CA: Pfeiffer, The Handbook of Blended Learning: Global Perspectives, Local Designs (pp. 3-21). San Francisco, Pfeiffer Publ.

11. Higgins, D., Gomez, A. (2014.) Teaching English studies through blended learning. URL: https://www.heacademy.ac.uk/ system/files/resources/ teaching_english_studies_through_blended_learning.pdf (accessed 29.04.2019).

12. Hofmann, J. (2014). Top 10 Challenges of Blended Learning (and Their Solutions!). URL: http://blog.insynctraining.com/top10-challenges-of-blended-learning (accessed 24.05.2019).

13. Khmyzova, O. (2014). The usage of information and communication technologies in teaching Business English at higher school, Proceedings. Scientific and Methodological Journal, Iss. 233. Pedagogy, 34 - 39. [in Ukrainian]

14. Korotun, O. (2016). Methodological bases of blended learning in the higher education, Information Technologies in Education, 3 (28), 117-129. [in Ukrainian]

15. Majumdar, A. (2014). Blended Learning: Different combinations that work. URL: https://www.gc-solutions.net/blog/blendedlearning-different-combinations-that-work/ (accessed 25.05.2019).

16. Marsh, D. (2012). Blended learning creating learning opportunities for language learners. Cambridge University Press.

17. Moskal, P., Dziuban C., Hartman J. (2013). Blended learning: A dangerous idea? The Internet and Higher Education, 18, 1523.

18. Nuruzzaman, A. (2016). The Pedagogy of Blended Learning: A Brief Review. IRA International Journal of Education and Multidisciplinary Studies, 4(1). doi: http://dx. doi.org/10.21013/jems.v4.n1.p14

19. Oliver, M., Trigwell, K. (2005). Can Blended Learning Be Redeemed? E-Learning, 2(1), 17-26. doi: https://doi.org/10.2304/elea.2005.2.1.17

20. Osguthorpe, R., Graham, C. R. (2003). Blended Learning Systems: Definitions and Directions. Quarterly Review of Distance Education, 4 (3), 227-233.

21. Porter, W., Graham, C. (2016). Institutional drivers and barriers to faculty adoption of blended learning in higher education. British Journal of Educational Technology, 47, 748-762. doi: 10.1111/ bjet.12269 
22. Sheri Spaine Long, LeAnn Derby, Lauren Scharf, Jean W. LeLoup, Daniel Uribe. Leadership Development and Language Learning: A Foundational Framework. URL: https://files.eric.ed.gov/fulltextEJ1080248.pdf (accessed 17.04.2019).

23. Staker, H., Horn, M (2012). Classifying K-12 Blended Learning. URL: https://www.christenseninstitute.org/wpcontent/uploads/2013/04/Classifying-K-12-blended-learning.pdf (accessed 15.05.2019).

24. Tryus, Y., Herasimenko, I. (2012). Blended Learning as an innovation educational technology in higher school, Theory and methods of e-learning, 3, 299-308. [in Ukrainian]

25. Wolpert-Gawron, H. (2011). Blended Learning: Combining Face-to-Face and Online Education. URL: https://www.edutopia.org/blog/blended-online-learning-heather-wolpert-gawron (accessed 28.05.2019).

26. Woodall, D. (2012). Blended Learning Strategies: Selecting the Best Instructional Method. URL: http://www.skillsoft.com/assets/white-papers/blended_learning_strategies_wp.pdf (accessed 27.05.2019).

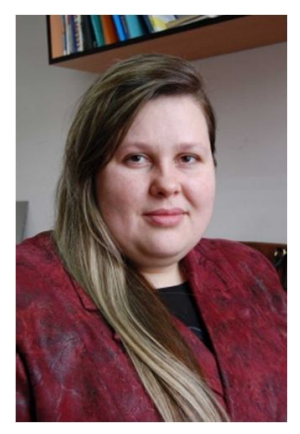

Хмизова Ольга Василівна.

Кандидат педагогічних наук, доцент, доцент кафедри економічної теорії та міжнародної економіки, Чорноморський національний університет імені Петра Могили,

вул. 68 Десантників, 10, Миколаїв, Миколаївська область, Україна, 54003.

Тел. +38(095)411-67-45. E-mail: sunnyflowers22@gmail.com

\section{Khmyzova Olga Vasylivna.}

Cand.Sc. (Pedagogical Sciences), Associate Professor, Department of Economic Theory and International Economics, Petro Mohyla Black Sea National University,

vul. 68 Desantnykiv, 10, Mykolaiv, Mykolaiv region, Ukraine, 54003.

Tel. +38(095)411-67-45. E-mail: sunnyflowers22@gmail.com

ORCID: 0000-0002-8671-3727

\section{Citation (APA):}

Khmyzova, O. (2019). The Use of Blended Learning Models in the Process of Business English Language Studying. Engineering and Educational Technologies, 7 (3), 64-74. doi: https://doi.org/10.30929/2307-9770.2019.07.03.06

\section{Цитування (ДСТУ 8302:2015):}

Хмизова О. В. Використання моделей змішаного навчання у процесі вивчення ділової англійської мови / Інженерні та освітні технологіiі. 2019. T. 7. № 3. С. 64-74. doi: https://doi.org/10.30929/2307-9770.2019.07.03.06

Обсяг статmі: $\quad$ сторінок-11; умовних друк. аркушів - 1,593. 